\title{
Actual Place of Diuretics in Hypertension Treatment
}

\section{Farouk Abcha, Marouane Boukhris*, Zied Ibn Elhadj, Lobna Laroussi, Faouzi Addad, Afef Ben Halima and Salem Kachboura}

Cardiology Department of Abderrahmen Mami Hospital, University of Tunis El Manar, Tunisia

Submission: February 03, 2017; Published: March 07, 2017

*Corresponding author: Marouane Boukhris, Cardiology Department of Abderrahmen Mami Hospital, Ariana, Faculty of Medicine of Tunis, University of Tunis El Manar, Tunisia, Tel: +216 22557125; Email: mar1bou@hotmail.com

\begin{abstract}
Diuretics represent a large and heterogeneous class of drugs, differing from each other by structure, site and mechanism of action. Diuretics are widely used, and have several indications in different cardiovascular disorders, particularly in hypertension and heart failure.

Despite the large number of available anti-hypertensive drugs, diuretics remained a cornerstone of hypertension treatment. In the current editorial, we assessed the actual place of different diuretics in the hypertension guidelines focusing on the concept of tailored approach in prescribing them for hypertensive patients.
\end{abstract}

Keywords: Diuretics; Hypertension; Hydrochlorothiazide; Indapamide; Guidelines

\section{Introduction}

Diuretics represent a large and heterogeneous class of drugs, differing from each other by structure, site and mechanism of action. Diuretics are widely used, and have several indications in different cardiovascular disorders, particularly in hypertension and heart failure.

Despite the large number of available anti-hypertensive drugs, diuretics remained a cornerstone of hypertension treatment [1]. Indeed, they are the second most commonly prescribed class of antihypertensive medication. For instance, $12 \%$ of US adults were prescribed a diuretic, and the relative increase in prescriptions from 1999 through 2012 was 1.4 [2]. However, a question remains looking for an answer: which diuretic for which hypertensive patient?

\section{Mechanisms of Action of Diuretics}

The overall action of diuretics (except osmotic diuretics) can be summarized as the blockage of sodium reabsorption at the nephron major sites leading to an increase in water excretion. Figure 1 illustrates the sites of action of different diuretic agents; Table 1 describes their mechanisms of action.

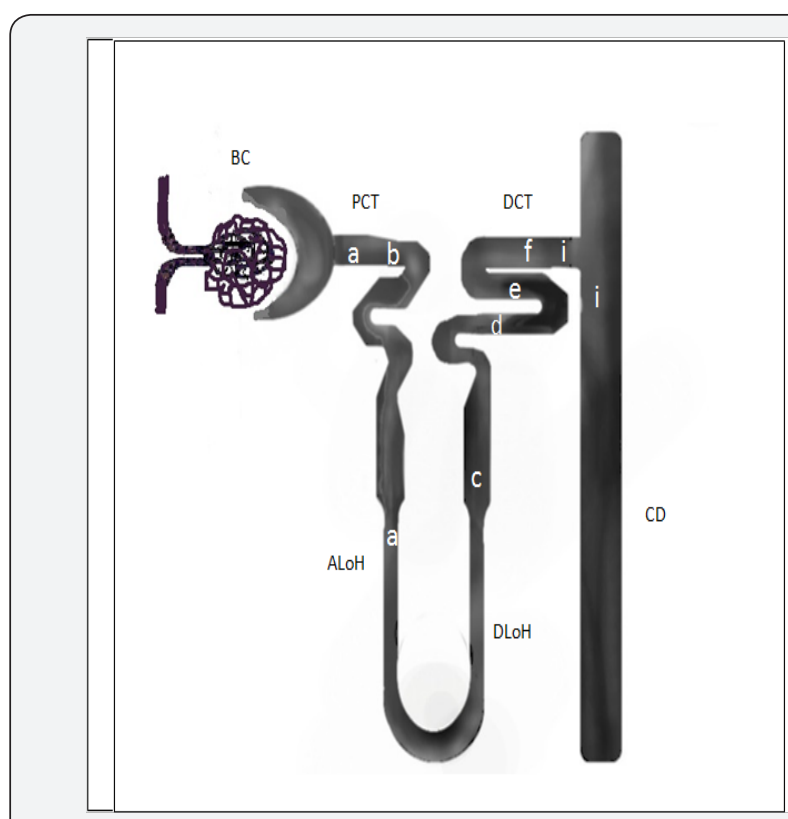

Figure 1: Site of action of different diuretic agents 
a: Osmotic diuretics; b: Carbonic anhydrase inhibitors; c: Loop diuretics: d: Indapamide \& Chlorthalidone; e: Hydrochlorothiazide; f: Amiloride \& Triamterene; i: Spironolactone.

Table 1: Mechanisms of action of diuretics agents.

\begin{tabular}{|c|c|c|}
\hline Diuretic* & Site of Action & Mechanisms \\
\hline Loop diuretics & Ascending loop of Henle & $\begin{array}{l}\text { Act directly on the ascending limb of the } \\
\text { loop of Henle to inhibit chloride and sodium } \\
\text { resorption by inhibiting } \mathrm{Na}+/ \mathrm{K}+/ 2 \mathrm{Cl}- \\
\text { transporter protein. Produce decrease in } \\
\text { interstitial hyper-tonicity and thus to a } \\
\text { reduced water reabsorption. }\end{array}$ \\
\hline \multicolumn{3}{|c|}{ Thiazide/ Thiazide like } \\
\hline Hydrochlorothiazide & Distal convoluted tubule & $\begin{array}{l}\text { Inhibits tubular resorption of sodium, } \\
\text { chloride, and potassium ions. Prevents } \mathrm{NaCl} \\
\text { reabsorption through direct suppression of } \\
\text { the sodium chloride co-transporter. Lowers } \\
\text { peripheral vascular resistance. }\end{array}$ \\
\hline Indapamide/chlorthalidone & $\begin{array}{l}\text { Proximal segment of the distal convoluted } \\
\text { tubule }\end{array}$ & $\begin{array}{l}\text { Inhibits tubular resorption of sodium, chloride } \\
\text { through blocking the sodium chloride co- } \\
\text { transporter with less effect on kaliuresis. } \\
\text { Reduces vascular reactivity. }\end{array}$ \\
\hline \multicolumn{3}{|c|}{ Potassium-Sparing Diuretics } \\
\hline Spironolactone & $\begin{array}{l}\text { Cortical collecting duct and late distal } \\
\text { convoluted tubule. }\end{array}$ & $\begin{array}{l}\text { Blocks the entry of aldosterone into the } \\
\text { principle cells by competitively binding to } \\
\text { aldosterone receptors. }\end{array}$ \\
\hline Amiloride/Triamterene & $\begin{array}{l}\text { Late distal convoluted tubule. Cortical } \\
\text { collecting duct. }\end{array}$ & $\begin{array}{l}\text { Prevents sodium entering by blocking the } \\
\text { epithelial sodium channel which are found in } \\
\text { the apical membrane. }\end{array}$ \\
\hline
\end{tabular}

${ }^{*}$ Carbonic anhydrase inhibitors and osmotic diuretics are not included.

In addition to their nephrogenic effects, some diuretics according to their structural proprieties can lower blood pressure via other pathways. For instance, indapamide has calcium antagonist-like vasorelaxant effects that strengthen its lowering blood pressure action [3]. Spironolactone likewise has another site of action on arterioles receptors, where it antagonizes aldosterone-induced vasoconstriction, resulting in diastolic and mean pressure reduction [4].

Nonetheless, the most worrying adverse effects of this class of agents is electrolytes derangement. Serum potassium level may be lowered by thiazides and loop diuretics and elevated by aldosterone antagonists. Hyponatremia is more common with chlorthaliadone than hydrochlorthiazide but not at equipotent doses and the incidence of hyponatremia for both medications is very strongly age related [5].

\section{Place of Diuretics in Hypertension Guidelines}

Formerly, diuretics were considered to be one of the most effective antihypertensive treatments. Nowadays, after the onset of new potent anti-hypertensive drugs, diuretics may be no longer considered the most privileged first-line strategy $[6,7]$.

Indeed, most of the current guidelines downgraded the place of thiazide diuretics in the management of hypertension from the preferential initial therapy to one of the possible first-line alternatives among a large armamentarium of anti-hypertensive drugs [8-12].
ALoH: Ascending Loop of Henle; BC: Bowman Capsule; CD: Collecting Duct; DCT: Distal Convoluted Tubule; DLoH: Descending Loop of Henle; PCT: Proximal Convoluted Tubule 


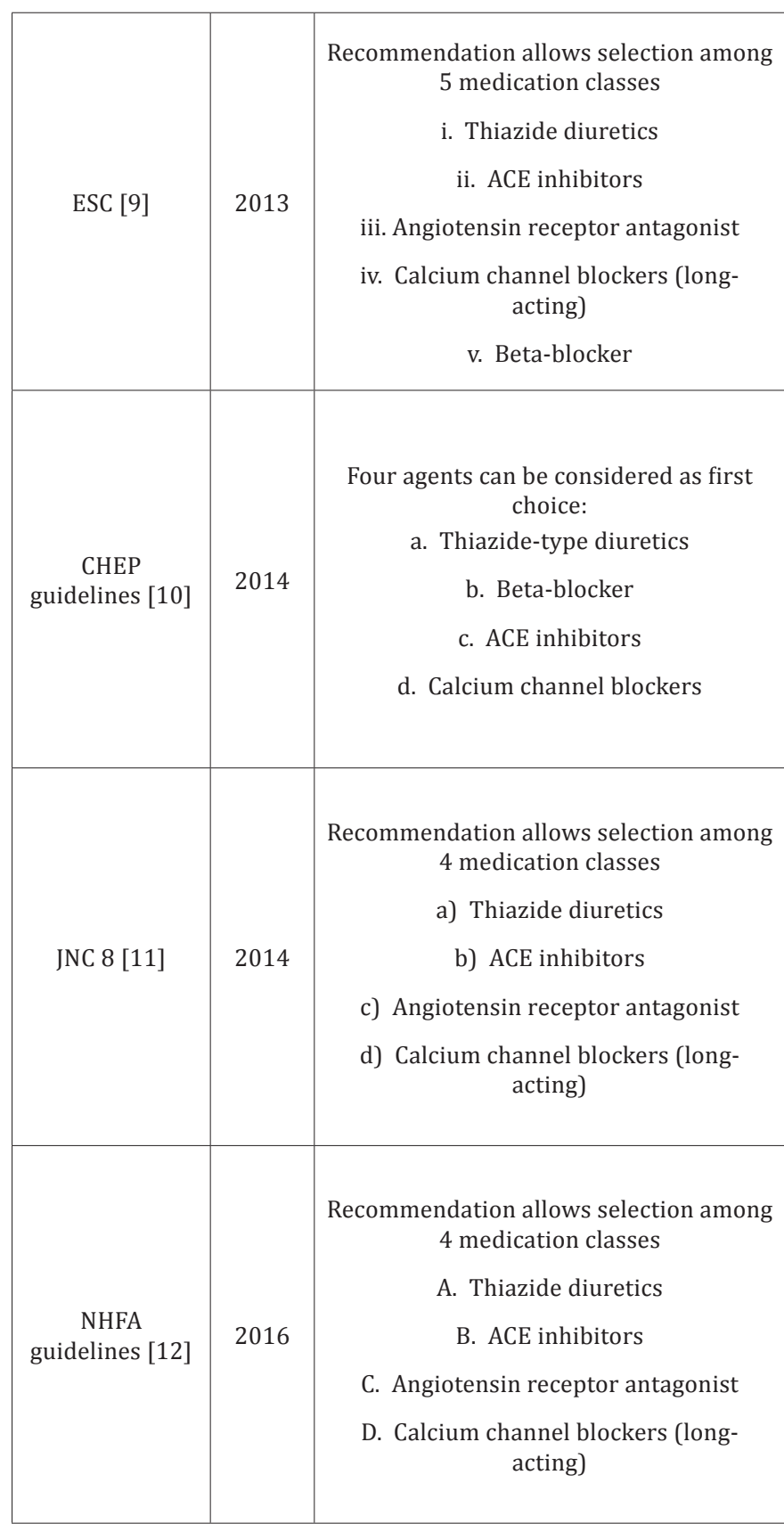

CHEP: Canadian Hypertension Education Program; ESC: European Society of Cardiology; JNC8: The Eighth Joint National Committee; NHFA: National Heart Foundation of Australia, NICE: National Institute for Health and Clinical Excellence; WHO: World Health Organization.

\section{The Concept of Tailored Approach}

Thiazide diuretics are privileged as the appropriate option in a variety of circumstances like for salt sensitive patients (such as black patients) and for those elderly with systolic hypertension [13]. In other clinical scenarios, they can be prescribed as one of 5 first-line antihypertensive alternatives [8-12].

However, other types of diuretics are barely mentioned in different guidelines and thereby are underutilized in daily practice [1]. Table 3 summarized the ideal clinical indications of each diuretic.
Table 3: Indications of different diuretic agents.

\begin{tabular}{|c|c|}
\hline Diuretics & Indications \\
\hline Loop diuretics & $\begin{array}{l}\text { Chronic kidney disease with } \\
\text { serum creatinine is }>1.5 \mathrm{mg} / \mathrm{dL} \\
\text { or eGFR is }<30 \mathrm{~mL} / \mathrm{min} / 1.73 \mathrm{~m}^{2} \\
\text { Volume overload Heart failure as } \\
\text { a second line therapy for volume } \\
\text { control }\end{array}$ \\
\hline \multicolumn{2}{|c|}{ Thiazide/Thiazide like } \\
\hline $\begin{array}{l}\text { If diuretic is to be initiated or } \\
\text { changed prefer indapamide or } \\
\text { chlorthalidone over conventional } \\
\text { hydrochlorothiazide }\end{array}$ & $\begin{array}{c}1^{\text {st }} \text { or } 2^{\text {nd }} \text { alternative particularly } \\
\text { in black patients and those aged } \\
>55 \text { years }\end{array}$ \\
\hline \multicolumn{2}{|c|}{ Potassium-Sparing Diuretics } \\
\hline $\begin{array}{l}\text { Mineralocorticoid receptor } \\
\text { antagonists }\end{array}$ & $\begin{array}{l}\text { Heart Failure Resistant } \\
\text { hypertension Primary } \\
\text { aldosteronism }\end{array}$ \\
\hline Amiloride & $\begin{array}{l}\text { Resistant hypertension } \\
\text { in addition to thiazide } \\
\text { or thiazide-like diuretics } \\
\text { Hyperaldosteronism if } \\
\text { spironolactone is not tolerated }\end{array}$ \\
\hline Triamterene & $\begin{array}{c}\text { Hyperaldosteronism if } \\
\text { spironolactone is not tolerated }\end{array}$ \\
\hline
\end{tabular}

eGFR: estimated Glomerular Fraction Rate.

\section{Thiazide and thiazide like diuretics}

Thiazide and thiazide like diuretics do not have the same structure neither the same site of action, and that would explain the huge disparities concerning their efficiency and side effects. Despite their differences, the recommendations generally do not favor any agent on the other [8-11]. Indeed, although recommendations encouraged a treatment approach based on considering patient's characteristics, the majority of guidelines are based on evidence for drug classes rather than individual drugs. Only Australian guidelines encourage when initiating or changing treatment, to prescribe a thiazide-like diuretic, such as chlorthalidone or indapamide in preference to a conventional thiazide diuretics [12].

Hydrochlorothiazide: Much evidence support the inferiority of hydrochlorothiazide compared to other thiazide like agents [1]. In fact, hydrochlorothiazide duration of antihypertensive action is less than 24 hour, while indapamide has even in the immediate release form, at least 24-hour duration of action for blood pressure reduction [14]. Duration of action is important in view of the fact that targeting nighttime blood pressure may reduce cardiovascular events [1]. Hydrochlorothiazide is also less potent than converting enzyme inhibitors, angiotensin receptor blockers, beta-blockers, and calcium channel blockers.

In a network analysis, hydrochlorothiazide alone was shown to be less effective in preventing cardiovascular events in comparison with chlorthalidone and the association hydrochlorothiazide-amiloride [15]. Furthermore, it is inferior to indapamide in improving endothelial function and longitudinal strain in patients with hypertension and diabetes 
[16]. Hydrochlorothiazide is also inferior to spironolactone in improving coronary flow reserve [17].

The only advantage of hydrochlorothiazide over both chlorthalidone and indapamide seems to be it extensive availability in formulations with other classes of antihypertensive drugs and his low price.

Indapamide: Many authors suggest that indapamide is by far the most efficient and tolerable diuretic for hypertensive patients [8]. Compared to hydrochlorothiazide, it was demonstrated to be more efficient in improving micro-albuminuria (in diabetics), reducing left ventricular mass index, inhibiting platelet aggregation, and reducing oxidative stress. Indapamide also proved its capacity to reduce left ventricular hypertrophy more than enalapril [18].

Another important feature, is that indapamide do not share with thiazide diuretics their adverse effects on lipid and glucide metabolism, thereby it can safely prescribed in diabetics patient [1].

Indapamide or chlorthalidone: The choice between indapamide and chlorthalidone is quite a relevant question. But the main obstacle that is faced to answer to this question is that there is no trial through literature that compares chlorthalidone and indapamide in the literature.

Kaplan [19] suggests that the choice between these 2 efficient drugs should be based on the 3 following criteria: (i) the ease of use; (ii) the cost; and (iii) hypokalemia which is a considerable drawback of chlorthalidone [8]. Indeed, the fall in serum potassium with $12.5 \mathrm{mg}$ doses of chlorthalidone is nearby $0.1 \mathrm{mmol} / \mathrm{L}$ greater than that seen with equivalent doses of hydrochlorothiazide [1].

The huge disparities of thiazides prescription may be due to that chlorthalidone is only commercialized with atenolol and azilsartan. Likewise, Indapamide is only combined with perindopril.

\section{Potassium sparing diuretics}

Both observational and randomized trials have shown that thiazide and thiazide-like diuretics (generally at higher doses) can cause ventricular ectopy and sudden death [1]; the addition of potassium-sparing diuretics might prevent it [20].

Furthermore, in elderly hypertensive patients, both amiloride and triamterene were showed to be efficient when combined to hydrochlorothiazide to reduce cardiovascular events compared to placebo [21]. While spironolactone did not show appropriate evidence for reducing cardiovascular events in hypertensive patients, its place in reducing total mortality in advanced heart failure is well known [22]. Moreover, its efficiency in resistant hypertension is well established [23].

Spironalctone has several others non blood pressure benefits like reducing proteinuria by $61 \%$ in proteinuric kidney disease, albuminuria by $60 \%$ in type 1 diabetes, and normalizing left ventricular hypertrophy in primary aldosteronism and low renin hypertension [1].

Both spironalactone and eplerenone are indicated in patients affected by heart failure. Although resulting in similar rates of hyperkalemia, eplerenone was shown to have greater impact on systolic blood pressure and to improve endothelial function in hypertensive patients [24,25].

\section{Loop diuretics}

Loop diuretics are mostly indicated as an alternative to thiazide diuretics in case of chronic kidney disease with serum creatinine is $>1.5 \mathrm{mg} / \mathrm{dL}$ or eGFR is $<30 \mathrm{~mL} / \mathrm{min} / 1.73 \mathrm{~m}^{2}$ [1]. The antihypertensive effect of low-dose loop diuretics could be improved with nighttime administration.

\section{Conclusion}

Diuretics area popular, heterogenousclassofantihypertensive drugs with several decades of clinical application. The concept to replace "one size fits all" paradigm to a more tailored approach in prescribing diuretics to hypertensive patients seems to be rational and appropriate for a better clinical benefit.

\section{References}

1. Roush GC, Sica DA (2016) Diuretics for Hypertension: A Review and Update. Am J Hypertens 29(10): 1130-1137.

2. Kantor ED, Rehm CD, Haas JS, Chan AT, Giovannucci EL (2015) Trends in Prescription Drug Use among Adults in the United States From 1999-2012. JAMA 314(17): 1818-1831.

3. Roush GC, Ernst ME, Kostis JB, Tandon S, Sica DA (2015) Head-tohead comparisons of hydrochlorothiazide with indapamide and chlorthalidone: antihypertensive and metabolic effects. Hypertension 65(5): 1041-1046.

4. Schohn DC, Jahn HA, Pelletier BC (1993) Dose-related cardiovascular effects of spironolactone. Am J Cardiol 71(3): 40A-45A.

5. van Blijderveen JC, Straus SM, Rodenburg EM, Zietse R, Stricker BH, et al. (2014) Risk of hyponatremia with diuretics: chlorthalidone versus hydrochlorothiazide. Am J Med 127(8): 763-771.

6. Whitworth JA, World Health Organization, International Society of Hypertension Writing Group (2003) 2003 World Health Organization (WHO)/International Society of Hypertension (ISH) statement on management of hypertension. J Hypertens 21(11): 1983-1992.

7. Mishra S (2016) Diuretics in primary hypertension-Reloaded. Indian Heart J 68(5): 720-723.

8. National Clinical Guideline Centre (UK) (2011) Hypertension: The Clinical Management of Primary Hypertension in Adults: Update of Clinical Guidelines 18 and 34. London: Royal College of Physicians (UK).

9. Mancia G, Fagard R, Narkiewicz K, Redon J, Zanchetti A, et al. (2013) $2013 \mathrm{ESH} / \mathrm{ESC}$ guidelines for the management of arterial hypertension: the Task Force for the Management of Arterial Hypertension of the European Society of Hypertension (ESH) and of the European Society of Cardiology (ESC). Eur Heart J 4(28): 2159-2219.

10. Dasgupta K, Quinn RR, Zarnke KB, Rabi DM, Ravani P, et al. (2014) The 2014 Canadian Hypertension Education Program recommendations for blood pressure measurement, diagnosis, assessment of risk, prevention, and treatment of hypertension. Can J Cardiol 30(5): 485501. 
11. James PA, Oparil S, Carter BL, Cushman WC, Dennison-Himmelfarb C, et al. (2014) 2014 evidence-based guideline for the management of high blood pressure in adults: report from the panel members appointed to the Eighth Joint National Committee (JNC 8). JAMA 311(5): 507-520.

12. Gabb GM, Mangoni AA, Anderson CS, Cowley D, Dowden JS, et al (2016) Guideline for the diagnosis and management of hypertension in adults- 2016. Med J Aust 205(2): 85-89.

13. Flack JM, Sica DA, Bakris G, Brown AL, Ferdinand KC, et al. (2010) Management of high blood pressure in Blacks: an update of the International Society on Hypertension in Blacks consensus statement. Hypertension 56(5): 780-800.

14. Roush GC, Ernst ME, Kostis JB, Kaur R, Sica DA (2015) Not just chlorthalidone: evidence-based, single tablet, diuretic alternatives to hydrochlorothiazide for hypertension. Curr Hypertens Rep 17(4): 540.

15. Roush GC, Holford TR, Guddati AK (2012) Chlorthalidone compared with hydrochlorothiazide in reducing cardiovascular events: systematic review and network meta-analyses. Hypertension 59(6): 1110-1117.

16. Vinereanu D, Dulgheru R, Magda S, Dragoi Galrinho R, Florescu M, et al. (2014) The effect of indapamide versus hydrochlorothiazide on ventricular and arterial function in patients with hypertension and diabetes: results of a randomized trial. Am Heart J 168(4): 446-456.

17. Garg R, Rao AD, Baimas-George M, Hurwitz S, Foster C, et al. (2015) Mineralocorticoid receptor blockade improves coronary microvascular function in individuals with type 2 diabetes. Diabetes 64(1): 236-242.

18. Kaplan NM (2015) Indapamide: is it the better diuretic for hypertension? Hypertension 65(5): 983-984.
19. Roush GC, Ernst ME, Kostis JB, Yeasmin S, Sica DA (2016) Dose doubling, relative potency, and dose equivalence of potassium-sparing diuretics affecting blood pressure and serum potassium: systematic review and meta-analyses. J Hypertens 34(1): 11-19.

20. Olde Engberink RH, Frenkel WJ, van den Bogaard B, Brewster LM, Vogt $\mathrm{L}$, et al. (2015) Effects of thiazide-type and thiazide-like diuretics on cardiovascular events and mortality: systematic review and metaanalysis. Hypertension 65(5): 1033-1040.

21. Pitt B, Zannad F, Remme WJ, Cody R, Castaigne A, et al. (1999) The effect of spironolactone on morbidity and mortality in patients with severe heart failure. Randomized Aldactone Evaluation Study Investigators. N Engl J Med 341(10): 709-717.

22. Dahal K, Kunwar S, Rijal J, Alqatahni F, Panta R, et al. (2015) The effects of aldosterone antagonists in patients with resistant hypertension: a meta-analysis of randomized and nonrandomized studies. Am J Hypertens 28(11): 1376-1385.

23. Pelliccia F, Patti G, Rosano G, Greco C, Gaudio C (2014) Efficacy and safety of eplerenone in the management of mild to moderate arterial hypertension: systematic review and meta-analysis. Int J Cardiol 177(1): 219-228.

24. Fujimura N, Noma K, Hata T, Soga J, Hidaka T, et al. (2012) Mineralocorticoid receptor blocker eplerenone improves endothelial function and inhibits Rho-associated kinase activity in patients with hypertension. Clin Pharmacol Ther 91(2): 289-297.

25. Hermida RC, Ayala DE, Mojón A, Chayán L, Domínguez MJ, et al. (2008) Comparison of the effects on ambulatory blood pressure of awakening versus bedtime administration of torasemide in essential hypertension. Chronobiol Int 25(6): 950-970.

\section{Your next submission with Juniper Publishers will reach you the below assets}

- Quality Editorial service

- Swift Peer Review

- Reprints availability

- E-prints Service

- Manuscript Podcast for convenient understanding

- Global attainment for your research

- Manuscript accessibility in different formats

( Pdf, E-pub, Full Text, Audio)

- Unceasing customer service

Track the below URL for one-step submission https://juniperpublishers.com/online-submission.php 